\title{
RAISING STANDARDS OF TEACHING AT A UNIVERSITY IN SAUDI ARABIA USING METHODS OF ACTIVE LEARNING
}

\author{
Fatmah Alotaibi ${ }^{1 *}$ and Roger Cutting ${ }^{2 * *}$ \\ ${ }^{1,2}$ Faculty of Arts \& Humanities Plymouth Institute of Education
}

\begin{abstract}
This paper explores the issue of teaching methods used at universities in Saudi Arabia and reports on a study into the implementation and effectiveness of 'active learning' techniques. While group and collaborative learning methods have long been used in such disciplines as the medical and physical sciences, many other courses and subjects at Saudi universities have continued to be taught in the traditional lecture format (albeit with the aid of computers and other technologies). But while lectures have some advantages they are not always an effective way of fostering learning, and they usually entail students being passive learners working in relative isolation. Not all educators are convinced of the value of other teaching approaches, and some prefer to continue to use traditional methods. Consequently, with the aim of helping elevate the quality of teaching in Saudi Arabia a project was undertaken to evaluate methods of 'active learning' that have been used for several years at a university in the city of Makkah. Several academics and students participated in a study in which active approaches were used in the teaching of undergraduate courses. Both qualitative and quantitative methods were employed to conduct and appraise the study; the results strongly confirmed the benefits of active learning, though they were by no means definitive. Indeed,while a majority of participating students found that the methods enhanced their learning, nevertheless a significant proportion reported that the approach made little difference to their ability to learn.
\end{abstract}

Keyw ords: Active learning, educational methods, learning strategies

\section{INTRODUCTION}

Saudi Arabia is a very conservative country in which traditions and customs are firmly entrenched. This conservatism is reflected in most aspects of life, including education, and the research project reported here must been seen within the context of a major national effort to elevate the standards and quality of the educational system at all levels. This project was undertaken because the traditional approach to teaching by way of lectures continues in common use in many courses in Saudi universities (Hamdan, 2014). Yet, in many other developed nations more active approaches to learning are being adopted, these being considered to be more effective for fostering learning by students (Richardson, 2005). Active learning (AL) does not just apply to the use of physical activities: rather, it refers to any form of educational method by which the learner actively participates and is involved in the educational process. It has been defined as any instructional method that engages students, that entails students doing meaningful learning activities, and requires students to take active responsibility for their own learning instead of being merely the passive recipients of information (Prince, 2004, p 1). It is an approach that"

$$
\begin{aligned}
& \text {... requires students to regularly } \\
& \text { assess their own degree of } \\
& \text { understanding and skill at handling } \\
& \text { concepts or problems in a } \\
& \text { particular discipline. The } \\
& \text { attainment of knowledge by } \\
& \text { participating or contributing. The } \\
& \text { process of keeping students } \\
& \text { mentally, and often physically, } \\
& \text { active in their learning through } \\
& \text { activities that involve them in }
\end{aligned}
$$

Corresponding Authors: *fatmah.alotaibi@ postgrad.plymouth.ac.uk, **roger.cutting@plymouth.ac.uk 
gathering information, thinking, and problem solving" (Collins \& O'Brien 2003).

The term can refer to subjects and topics at all levels, but today it more commonly applies to educational approaches used at tertiary levels (Lewis, 2004). An objective of AL is that it requires students to engage in activities such as analysis and evaluation, all of which entail higherorder thinking. It describes methods that encourage learners to think critically about content, and it benefits learners by providing challenging situations that may involve evaluative, problem solving, or reasoning skills (Lewis, 2004: Prince, 2004: Collins \& O’Brien, 2003).

Expositional and didactic approaches to teaching are often predicated on the assumption that all students can adequately acquire learning by listening and making notes, and that they need the same information at the same time and place in a one- way information transfer. But listening to a lecture is only of value to students who learn best by listening (Silberman, 1996; Weimer 2002; Chance 2005), and AL is in marked contrast to such methods. However, despite its reported benefits (Millis \& Cottell, 1998: Cranton 2012: McKinney 2012) AL it is not always practiced by teachers (Lewis, 2004). Lecturing continues in common use because it is a quick way of transmitting a large amount of information, and it may not require much preparation by the lecturer. However, researchers such as Bangert (2004) argue that it is an inefficient technique because the learners remain relatively inactive, cannot always retain the information, or become inattentive; instead, he argues that students need to do more than just listen - they must be participators by writing, discussing, reading, or being otherwise engaged in solving problems. A feature of AL is that it is largely student-centred; the student takes responsibility for managing his/her own learning program, and according to Kuh (2008), widespread literature has established the value of active, engaged, and collaborative methods of learning for students (Baeten et al, 2010: Robinson, 2011).

\section{Active Learning}

AL can take a number of forms, and examples include practical tasks, collaborative learning, case studies, peer learning, enquiry-based learning, and project-based learning. Many of these activities involve groups. Described variously as collaborative, cooperative, or peer learning, they can refer to any tasks or methods in which students work together in small groups on a common issue (Millis \& Cottell, 1998). Similarly, many activities require learners to address problems that are introduced at the beginning of the session and then used to provide the motivation and context for the learning activities that follow (Wood 2003: Armstrong 2008: Yew \& Schmidt 2011). Typically, the problem to be solved is a vehicle for stimulating cognitive processes and for reinforcing principles, practices, or other subject details.

The literature contains a number of studies in support of AL techniques (Cranton 2012: McKinney 2012). Reporting on a survey of 6,000 physics students, Hake (1998) noted that students in classes where AL methods were used achieved significantly higher scores on a standard test of physics knowledge than students who attended traditional, lecture-based courses. Similar results for students of physics were also stated by Hoellwarth and Moelter (2011) who reported that learners who used AL improved by 38 percentage points when evaluated on a standardised test. Michael (2006, Table 1) and Michael and Modell (2004) listed a number of $\mathrm{AL}$ approaches such as enquiry-based learning, discovery learning, and technology-enhanced learning which have been demonstrated to yield markedly higher levels of learning in the medical sciences. Baldwin (2014) concluded that AL should be a key element of all tertiary courses, and other supportive research is provided by Walker (2003) who examined the influence of AL on critical thinking, and Hackathorn et al (2011, p 40) who found that "In-class activities led to higher overall scores than any other teaching method while lecture methods led to the lowest overall scores of any of the teaching methods." 
Despite the evidence and the arguments provided by writers such as those cited above, some educators at university level still avoid using AL methods. Lewis (2004) suggested inertia and resistance by older academics, and Prince (2004, p7) concluded that "...tyranny encourages faculty to push through as much material as possible in a given session”. Plush and Kehrwald (2014) note that there are practical impediments, especially for younger tertiary-level teachers. The authors observed that some teachers may themselves have only experienced the traditional lecture format and may not be adequately supported while developing their own teaching style (Plush \& Kehrwald, 2014). While concluding that, overall, several techniques for AL enhance learning, Prince (2004, $\mathrm{p}$ 7) acknowledges that the purported improvements resulting from some methods of active engagement are doubtful. He notes, for example, that there is little evidence to support the claim that group discussions lead to improved learning, and he states that team activities can diminish individual responsibility and effort. He comments, too, that problembased-learning is unlikely to improve students' test scores but that it positively influences student attitudes and study habits (Prince, 2004, p 7).

In the light of these varying results it is important now to consider the relationship of $\mathrm{AL}$ to the current theories of learning.

\section{AL and theories of learning}

The use of AL is concordant with various pedagogical theories, principles, and concepts that have been developed over the years. Traditional theories of learning, and the use of didactic methods, considered knowledge to be a commodity capable of being transmitted by simple and direct means (Bransford et al. 2006), and when learned it could then be reproduced. In contrast, AL is founded on the theories of knowledge as something each learner constructs or creates afresh rather than something that is absorbed and memorised in its pre-existing form (Greeno, 2006: Sawyer, 2006).

It is not possible here to review all recent learning theories, but many forms of $\mathrm{AL}$ entail collaboration through group activities on the premise that people learn from each other, and writers such as Vygotsky (1962, 1976), Bandura, (1986) and Ormrod (2008) have proposed social learning theories to explain how people learn in social settings. That is, learning is a cognitive process that occurs within social contexts where cognition, environment, and behaviour all influence each other to foster understanding. Social process concepts suggest cooperative strategies (Schunk

2008) that enhance deeper knowledge construction underpinned by student discussions; they also build active learning communities out of small, group-based instruction.

AL methods also meet the tenets of constructivism, which is an important paradigm for learning processes. This model depicts learning as the result of 'constructed' understanding. For instance, Driver et al. (1989, 2007) and Duffy et al (2012) expound the view that knowledge must be constructed by the mental activity of learners who construct meaning from previously-acquired information. Teaching should provide active learning environments that, in turn, produce interpretable experiences and facilitate knowledge construction. The construction of meaning is facilitated by making multiple links between the information being acquired and the existing store of information. Information and meaning (whether old or new) are assembled into mental models or representations which are the basis of learning.

Additionally, it is pertinent to consider experiential learning theory which is very relevant to $\mathrm{AL}$ because it confirms the importance of personal involvement and practices in building knowledge (Kolb \& Kolb 2008: Moon 2004). This theory highlights the value of $\mathrm{AL}$ because it shows that learners are better able construct knowledge and understanding by way of participation and by the opportunity to reflect on what they have done. The theory views learning as an on-going process (Dewey, 1897, 79: Sawyer 2006), as an opportunity to re-learn, as the resolution of conflicts between different ideas and concepts, and as the creation of knowledge - an approach that is fundamentally different from the traditional 'transmission' model whereby pre- 
existing information is conveyed to the learner (Pashler et al, 2008).

These and other current theories confirm the need for teachers to develop approaches which are more effective for constructing learning, but modern theories and practices can be slow to be recognised and so before detailing the project conducted in Saudi Arabia it is important now to outline the current Saudi education system of that country.

\section{Education in Saudi Arabia}

The research reported here represents one aspect of the Saudi government's programme for elevating the nation's educational methods and standards at all levels. Saudi traditions and conservatism are reflected in the educational system, and AL is a method relatively new in the Kingdom, particularly to the tertiary sector, even though the educational system has developed very rapidly over the past fifty years (Bahgat, 1999: Country Studies, 2006).

Traditional views of education have, in the past, resulted in students giving precedence to their Arabic values and to Islamic studies, and until recently many graduates were ill-prepared for employment or careers. At tertiary levels much has changed in recent decades and many courses make greater use of laboratory and research techniques of learning. Nevertheless, despite these improvements, too often courses are taught by means of traditional lecturing methods, as described by House (2012) and Johnson (2009, p24); “... teachers encourage a system of ineffective memorization and a superficial understanding of facts for the sole purpose of passing a test. This type of education extends ... to the college and university levels. Students are continuously taught of ways to pass an exam rather than the proper approaches to learning". The urgent need to promote more effective ways of learning and to encourage the adoption of better methods form the backdrop and the reason for the enquiry reported here.

While conservatism remains strong, for the past decade or so there has been a vigorous debate regarding the scope, content, and methods of education (Alsadaawi, 2010). Traditional approaches to teaching have been challenged, the government acknowledging the need to develop and reform the state education system as a key component in the nation's economic development plans (Yamani, 2006). Consequently, the government has invested heavily in educational institutions, but this strategy increased the number of graduates quantitatively not qualitatively, as Saudi universities continued to produce less than capable graduates, adding to the ranks of the unemployed (Bosbait and Wilson, 2005). Indeed, as explained by Alsadaawi (2010) there has been agreement among educators, researchers, and policymakers that the Saudi education system has not been achieving best practices or standards. The educational challenge facing the country has been the need to prepare students for a competitive workforce by emphasising the quality of teaching in all disciplines through the adoption of best practice in teaching and learning methodologies.

In response to the Saudi government's programme of educational improvement this project was conducted to demonstrate that AL offers a more effective approach to learning.

\section{RESEARCH AIMS}

The questions posed for this research were:

1. Which AL strategies do students at a university in Saudi Arabia find most useful?

2. What are the perceptions of students with regard to how AL strategies affected their learning?

\section{METHODOLOGY}

The interpretivist aspect of this work is based on the theoretical belief that reality is socially constructed and fluid within cultures, social settings, and relationships with other people. Moreover, there can be multiple, valid claims to knowledge (Guba \& Lincoln, 1994, pp 105117). Interpretivism has a long tradition in the social sciences and interpretivists aim for a detailed description and understanding of the phenomenon under investigation by way of observation and involvement (Bryman, 1994: 
Saunders et al, 2007). This philosophical approach is reflected in the qualitative methods adopted and aims to provide an insight into organisational and social processes as well as on the way people think and behave (Creswell. 2013).

\section{Research method: questionnaires, interviews, and focus groups}

The mixed methods selected for this investigation included questionnaires, interviews, and focus groups, and together these methods produced a range of triangulated data that addressed issues of validity and reliability. From an ontological point of view, this study was based on the assumption that "people's knowledge, views, understanding, interpretation, experiences and interactions are meaningful" (Mason, 2002:63). Additionally, the use of interviews allow for social exchange to construct "depth, nuance, complexity and roundness in data" (Mason, 2002:65), and focus groups provide the researcher with the perceptions of the participants regarding active learning (Korpel, 2005).

Focus groups are very useful for understanding people's perceptions and thoughts about a phenomenon. The participants are selected based on common characteristics and their links to the research topic (Greenbaum, 1998; Krueger and Casey, 2000). It has the advantage of yielding differing experiences, and the cross- current of views can prompt unexpected information. However, it too can be difficult to analyse, it may suffer from bias, and it requires a skilled facilitator (Krueger \& Casey, 2000: Creswell, 2012).

\section{The research site}

The site for this investigation was the College of Engineering, the College of Computer Science, and the Business School at Umm Al Qura University in Saudi Arabia. All ethical issues and research protocols were addressed. Approvals were obtained from the University of Plymouth and from these three colleges for the researcher to recruit student participants who had completed their first year of study. All approvals were granted in writing, and the initial step involved the deans distributing the questionnaire to participants by way of teachers in the respective colleges.

\section{The subject}

Commencing in 2010 several sections of the three colleges had adopted AL methods though it must be noted that most departments and faculties within the university continued to apply their existing methods of instruction. This project surveyed both students' experiences of classes in which AL methods were applied, and the experiences and views of the teachers who had implemented AL techniques. The researcher did not conduct or otherwise influence the nature or scope of existing AL approaches; rather she aimed to assess the educational worth of the system being used. This survey sought to identify which techniques (if any) benefited or hindered the ability of students to learn the required topics and subjects. The following aspects of the $\mathrm{AL}$ program were evaluated by the questionnaire, interviews, and group discussion:

- Classroom arrangement

- $\quad$ Group-work methods

- $\quad$ Learning activities

- $\quad$ Learning processes

- $\quad$ Educational development

- Personal and educational outcomes

\section{The sample}

Two samples were selected for this enquiry students and teachers.

A sample of student participants (Table 1) was selected by means of probability sampling, a technique which entails some form of random selection to ensure a representative cross-section (Landreneau, 2005). The limitation was that the participants must have completed the first year of their course. The participants were aged between 18 and 20. The questionnaire was designed for male and female respondents but ultimately only male students were allowed to participate. 
Table 1: Classification of college students in our sample

\begin{tabular}{|l|l|l|l|l|}
\hline & $\begin{array}{l}\text { College of } \\
\text { Engineering }\end{array}$ & $\begin{array}{l}\text { College } \\
\text { of } \\
\text { Computer } \\
\text { Science }\end{array}$ & $\begin{array}{l}\text { Business } \\
\text { School }\end{array}$ & $\mathrm{N}$ \\
\hline Samples & 88 & 38 & 63 & 189 \\
\hline Participants & 76 & 27 & 62 & 165 \\
\hline $\begin{array}{l}\text { Response } \\
\text { rate }\end{array}$ & $86 \%$ & $71 \%$ & $98 \%$ & $87 \%$ \\
\hline
\end{tabular}

\section{The questionnaire}

A first draft of the questionnaire was compiled, then piloted and refined. The questionnaire comprised 35 questions divided into seven categories, and it was sent to all participants. One hundred and sixty five responded (87 percent). The initial questions were quite simple to make respondents feel comfortable and confident. The language was formal, but easy to understand, and the response boxes and scales were clearly laid out and unambiguous. A fivepoint Likert-type scale was used for recording the responses.

\section{Focus group}

Three teachers from the 32 respondents (who had been nominated by the head of the active learning program) were chosen for a group discussion. The facilitator (who was not the researcher) posed several prepared questions in order to initiate discussion, but then partipants were invited to contribute comments, experiences, and ideas. The one-hour discussion was audio-recorded (with approval) for later analysis.

\section{Interviews}

Thirty-two teachers were invited to be interviewed. Two student representatives, selected randomly from the cohort, were also interviewed. The duration of the audio- recorded interviews was approximately 45 minutes and were conducted in a meeting room at the Business College. The interviews were semi-structured, the interviewer asking eleven prepared questions which focussed on the use and effectiveness of AL, but also inviting comments and any other relevant information. All of the interviewees were asked the same questions in the same manner. Non-threatening questions were used to begin with to put the interviews at ease. The questions were designed to confirm or complement the questions in the questionnaire.

\section{Reliability and Validity}

The value of a research project depends largely on reliability and validity. The former refers to the degree to which the methodology produces stable and consistent results and is able to yield the same or compatible results in different clinical trials (Cohen et al 2007: Creswell 2003). In this investigation reliability was ensured by means of using different people to assist in the preparation of the questionnaire and the interview questions, the use of another person as facilitator for the interviews and group discussions, and using different raters to appraise the participants' responses. Research validity applies to both the design and the methods of data collection and it means that the findings truly represent the phenomenon they claim to measure (Creswell 2003: Silverman 2011). In this project internal consistency reliability were ensured by the use of Cronbach's alpha. This measure is a coefficient of consistency between variables and is written as a function of the number of test items and the average inter-correlation between them. It is widely used in qualitative research and is regarded as a good indicator of consistency (Allen \& Yen, 2002).

Alpha can have values between 0.0 and 1.0; (DeVellis, 1991), in general values below .65 are undesirable, .65 to .70 are acceptable, .70 to .80 are good, and above. 80 are considered to indicate high levels of validity.

\section{RESULTS}

\section{The setting}

Unlike the formal arrangements typically used in lecture halls, the AL program used informal seating that facilitated group work. Table 2 summarises the experiences of the students in response to this system. It can be seen that a 
majority (83 percent) felt that the informal arrangement was beneficial. It can also be seen that most (53 percent) found group work to be a helpful way of learning - though the result was not particularly strong.

Table 2: Informal classroom arrangement

\begin{tabular}{|c|c|c|c|c|c|c|}
\hline The items & $\begin{array}{l}\text { Vary } \\
\text { Useful }\end{array}$ & Useful & $\begin{array}{l}\text { No } \\
\text { difference }\end{array}$ & Not Useful & $\begin{array}{l}\text { Not very } \\
\text { useful }\end{array}$ & Total \\
\hline $\begin{array}{l}\text { Informal } \\
\text { classroom } \\
\text { arrangement }\end{array}$ & $\begin{array}{l}83 \\
(50.3)\end{array}$ & $\begin{array}{l}54 \\
(32.7)\end{array}$ & $\begin{array}{l}13 \\
(7.9)\end{array}$ & $6(3.6)$ & $9(5.5)$ & $\begin{array}{l}165 \\
(100.0)\end{array}$ \\
\hline $\begin{array}{l}\text { Working in } \\
\text { small groups }\end{array}$ & $\begin{array}{l}58 \\
(35.2)\end{array}$ & & & & & \\
\hline
\end{tabular}

\section{Learning activities}

To discover which activities they preferred, students were asked to indicate which activity they found to

Table 3: The learning activities be useful. As seen in table 3 most students reported positive experiences of learning by interacting with other students and with the tutor.

\begin{tabular}{|l|l|l|l|l|l|l|}
\hline The items & $\begin{array}{l}\text { Very } \\
\text { Useful }\end{array}$ & Useful & $\begin{array}{l}\text { No } \\
\text { difference }\end{array}$ & Not useful & $\begin{array}{l}\text { Not very } \\
\text { useful }\end{array}$ & Total \\
\hline Learning by discussion & $68(41.2)$ & $50(30.3)$ & $28(17.0)$ & $10(6.1)$ & $9(5.5)$ & $165(100.0)$ \\
\hline $\begin{array}{l}\text { Learning through } \\
\text { personal research }\end{array}$ & $63(38.2)$ & $43(26.1)$ & $36(21.8)$ & $13(7.9)$ & $10(6.1)$ & $165(100.0)$ \\
\hline $\begin{array}{l}\text { Learning by interacting } \\
\text { with the tutor }\end{array}$ & $76(46.1)$ & $40(24.2)$ & $30(18.2)$ & $6(3.6)$ & $13(7.9)$ & $165(100.0)$ \\
\hline
\end{tabular}

The majority of respondents $(71.5 \%)$ reported that learning by discussion with peers was beneficial, and about the same proportion $(70.3 \%)$ found it helpful to interact with the tutor. However, an interesting response was evident here because $62.3 \%$ also stated that they learned though personal research. It appears that these responses were not contradictory; rather, they were complementary insofar as there are occasions when peer-assistance can be helpful but at the same time students learn much from private study.

\section{The learning process}

The respondents were asked to indicate the usefulness of nine AL activities. Table 4 summarises the learning process activities. Perhaps the most distinctive feature of this table is that there was considerable consistency between the results of the different AL techniques. 
Table 4: The learning process

\begin{tabular}{|c|c|c|c|c|c|c|}
\hline The items & $\begin{array}{l}\text { Very } \\
\text { useful }\end{array}$ & Useful & $\begin{array}{l}\text { No } \\
\text { difference }\end{array}$ & $\begin{array}{l}\text { Not } \\
\text { useful }\end{array}$ & $\begin{array}{l}\text { Not very } \\
\text { useful }\end{array}$ & Total \\
\hline $\begin{array}{l}\text { Keeping a reflective } \\
\text { journal }\end{array}$ & $\begin{array}{l}60 \\
(36.4)\end{array}$ & $\begin{array}{l}51 \\
(36.4)\end{array}$ & $\begin{array}{l}30 \\
(18.2)\end{array}$ & $\begin{array}{l}17 \\
(10.3)\end{array}$ & $7(4.2)$ & $\begin{array}{l}165 \\
(100.0)\end{array}$ \\
\hline $\begin{array}{l}\text { Discussion in small } \\
\text { groups }\end{array}$ & $\begin{array}{l}68 \\
(41.2)\end{array}$ & $\begin{array}{l}49 \\
(29.7)\end{array}$ & $\begin{array}{l}28 \\
(29.7)\end{array}$ & $\begin{array}{l}11 \\
(6.7) \\
\end{array}$ & $9(5.5)$ & $\begin{array}{l}165 \\
(100.0)\end{array}$ \\
\hline Individual research & $\begin{array}{l}67 \\
(40.6)\end{array}$ & $\begin{array}{l}48 \\
(29.1)\end{array}$ & $\begin{array}{l}33 \\
(20.0)\end{array}$ & $\begin{array}{l}11 \\
(6.7)\end{array}$ & $6(3.6)$ & $\begin{array}{l}165 \\
(100.0)\end{array}$ \\
\hline $\begin{array}{l}\text { Doing } \\
\text { presentations } \quad \text { to class }\end{array}$ & $65(39.4)$ & $45(27.3)$ & $31(18.8)$ & $17(10.3)$ & $7(4.2)$ & $165(100.0)$ \\
\hline $\begin{array}{l}\text { Writing } \\
\text { reports }\end{array}$ & $70(42.4)$ & $40(24.2)$ & $38(23.0)$ & $9(5.5)$ & $8(4.8)$ & $165(100.0)$ \\
\hline Feedback to class & $\begin{array}{l}70 \\
(42.4)\end{array}$ & $\begin{array}{l}46 \\
(27.9)\end{array}$ & $\begin{array}{l}31 \\
(18.8)\end{array}$ & $\begin{array}{l}13 \\
(7.9)\end{array}$ & $5(3.0)$ & $\begin{array}{l}165 \\
(100.0)\end{array}$ \\
\hline $\begin{array}{l}\text { Completing } \\
\text { worksheets }\end{array}$ & $\begin{array}{l}64 \\
(38.8)\end{array}$ & $\begin{array}{l}52 \\
(31.5)\end{array}$ & $\begin{array}{l}31 \\
(18.8)\end{array}$ & $\left(\begin{array}{l}10 \\
(6.1)\end{array}\right)$ & $8(4.8)$ & $\left(\begin{array}{l}165 \\
(100.0)\end{array}\right)$ \\
\hline $\begin{array}{l}\text { Watching power point } \\
\text { presentations by the tutor }\end{array}$ & $69(41.8)$ & $43(26.1)$ & $28(17.0)$ & $9(5.5)$ & $16(9)$ & $165(100.0)$ \\
\hline $\begin{array}{l}\text { Handouts } \\
\text { class/checklists }\end{array}$ & $\begin{array}{l}52 \\
(31.5)\end{array}$ & $\begin{array}{l}64 \\
(38.8)\end{array}$ & $\begin{array}{l}29 \\
(17.6)\end{array}$ & $\begin{array}{l}12 \\
(7.3)\end{array}$ & $8(4.8)$ & $\begin{array}{l}165 \\
(100.0)\end{array}$ \\
\hline
\end{tabular}

That is, for all of the methods over two-thirds of students reported that their learning benefited. The methods that apparently yielded least benefits were essays and reports $(66.6 \%)$, and the most helpful was discussions (70.9\%). It is also pertinent to note that while the use of a journal scored highly (72.8\% reported a benefit), a relatively high proportion (14.5\%) stated that the journal was of no educational value. The methods for which there was least support, and which about one-third of participants found to be of no value, were the journal, student presentations, and power-point presentations by tutor.

\section{Educational development}

Students were asked to score the benefits to their own learning as a result of the active learning techniques. In comparison with the results of Table 4 , the personal educational benefits recorded in Table 5 were noticeably lower. Considered overall, the majority of respondents stated that they received positive learning experiences from AL, though the scores were clearly lower than in the previous table. 
Table 5: Educational development

\begin{tabular}{|l|l|l|l|l|l|l|}
\hline The items & $\begin{array}{l}\text { Very } \\
\text { Useful }\end{array}$ & Useful & $\begin{array}{l}\text { No } \\
\text { difference }\end{array}$ & $\begin{array}{l}\text { Not } \\
\text { Useful }\end{array}$ & $\begin{array}{l}\text { Not } \\
\text { very useful }\end{array}$ & Total \\
\hline $\begin{array}{l}\text { Improved your ability to understand the } \\
\text { course material }\end{array}$ & $50(30.3)$ & $45(27.3)$ & $37(22.4)$ & $10(6.1)$ & $23(6.1)$ & $165(100.0)$ \\
\hline $\begin{array}{l}\text { Made you aware of your own } \\
\text { responsibility in the learning process }\end{array}$ & $47(28.5)$ & $46(27.9)$ & $37(22.4)$ & $20(12)$ & $15(9.1)$ & $165(100.0)$ \\
\hline $\begin{array}{l}\text { Enabled you to analyse problems more } \\
\text { effectively }\end{array}$ & $68(41.2)$ & $49(29.7)$ & $32(19.4)$ & $9(5.5)$ & $7(4.2)$ & $\begin{array}{l}165 \\
(100.0)\end{array}$ \\
\hline $\begin{array}{l}\text { Helped you to find solutions to } \\
\text { problems more effectively }\end{array}$ & $48(29.1)$ & $58(35.2)$ & $37(22.4)$ & $14(8.5)$ & $8(4.8)$ & $\begin{array}{l}165 \\
100.0)\end{array}$ \\
\hline Improved your communication skills & $59(35.8)$ & $37(22.4)$ & $49(29.7)$ & $11(6.7)$ & $9(5.5)$ & $\begin{array}{l}165 \\
(100.0)\end{array}$ \\
\hline Improved your level of confidence & $53(32.1)$ & $51(30.9)$ & $41(24.8)$ & $14(8.5)$ & $6(3.6)$ & $\begin{array}{l}165 \\
(100.0)\end{array}$ \\
\hline
\end{tabular}

The greatest reported benefit was that AL enabled the students to analyse problems more effectively (70.9 percent). The positive scores for 'personal responsibility for learning' (56.4\%) and 'improved understanding of course material' (57.6 percent) were recorded by more than half of the respondents, but these were by no means strong endorsements of AL. Indeed, the fact that so many (43.6\%) did not acknowledge increased personal responsibility for their own learning as a result of AL appears to somewhat contradict the claims of other writers (cited above).

\section{Skills}

Many aspects of learning entail the acquisition of skills of different sorts. Students were asked which of the skills that they learned were most useful with respect of making presentations. Table 6 shows that considered overall, more than half recorded benefiting from $\mathrm{AL}$, though the figure was not particularly high, with less than about two-third of the respondents reporting that the skills they learned were of benefit when preparing and conducting presentations.

Table 6: Skills

\begin{tabular}{|l|l|l|l|l|l|l|}
\hline The items & Very Useful & Useful & $\begin{array}{l}\text { No } \\
\text { difference }\end{array}$ & $\begin{array}{l}\text { Not } \\
\text { Useful }\end{array}$ & $\begin{array}{l}\text { Not very } \\
\text { useful }\end{array}$ & Total \\
\hline Research skills & $69(41.8)$ & $25(15.2)$ & $46(27.9)$ & $12(7.3)$ & $13(7.9)$ & $\begin{array}{l}165 \\
(100.0)\end{array}$ \\
\hline Planning skills & $47(28.5)$ & $59(35.8)$ & $37(22.4)$ & $14(8.5)$ & $8(4.8)$ & $\begin{array}{l}165 \\
(100.0)\end{array}$ \\
\hline I.T. skills & $63(38.2)$ & $45(27.3)$ & $37(22.4)$ & $13(7.9)$ & $7(4.2)$ & $165(100.0)$ \\
\hline Public speaking skills & & & & & & 165 \\
& $58(35.2)$ & $53(32.1)$ & $33(20.0)$ & $12(7.3)$ & $9(5.5)$ & $(100.0)$ \\
\hline
\end{tabular}


While these figures confirm the value of AL, nevertheless it is surprising that the proportions are not higher considering that research, planning, and IT skills are central to many courses undertaken by tertiary students.

\section{Class discussion}

\section{Table 7: Class discussion}

\begin{tabular}{|c|c|c|c|c|c|c|}
\hline The items & $\begin{array}{l}\text { Very } \\
\text { Useful }\end{array}$ & Useful & $\begin{array}{l}\text { No } \\
\text { difference }\end{array}$ & $\begin{array}{l}\text { Not } \\
\text { Useful }\end{array}$ & $\begin{array}{l}\text { Not } \\
\text { very } \\
\text { useful }\end{array}$ & Total \\
\hline $\begin{array}{l}\text { Made you aware of other } \\
\text { points of view }\end{array}$ & 64 (38.8) & $42(25.5)$ & $35(21.2)$ & $13(7.9)$ & $11(6.7)$ & $\begin{array}{l}165 \\
(100.0)\end{array}$ \\
\hline $\begin{array}{l}\text { Helped you to argue a } \\
\text { point effectively }\end{array}$ & $56(33.9)$ & $48(33.9)$ & $39(23.6)$ & $16(9.7)$ & $6(3.6)$ & $\begin{array}{l}165 \\
(100.0)\end{array}$ \\
\hline $\begin{array}{l}\text { Improved your } \\
\text { communication skills }\end{array}$ & $59(35.8)$ & $42(25.5)$ & $41(24.8)$ & $15(9.1)$ & $8(4.8)$ & $\begin{array}{l}165 \\
(100.0)\end{array}$ \\
\hline $\begin{array}{l}\text { Helped to develop } \\
\text { analytical skills }\end{array}$ & 65 (39.4) & $46(27.9)$ & $29(17.6)$ & $12(7.3)$ & $13(7.9)$ & $165(100.0)$ \\
\hline
\end{tabular}

The highest score was for 'development of analytic skills' (67.3 percent), and this might be expected because analysis is such an important part of many academic subjects. Yet a high proportion (15.2 percent) said that their analytical skills had not been helped by AL methods. Interestingly, only 61.3 percent reported that $\mathrm{AL}$ benefited their communication skills, yet good communication is such an important ability for many in the areas of engineering, science, and business.
Discussions in various formats are often used in AL situations. In this instance students were asked what they had gained from class discussions. From table 7 , it is appear that the majority of respondents recorded experiencing positive benefits from group discussions of class topics and problems.

\section{Personal development from AL}

Education is not just about measurable learning outcomes. It has personal, emotional, cultural, and intellectual effects too. Students were asked if active learning had been useful for their personal development. Table 8 also demonstrates overall positive personal experiences stemming from AL. The greatest recorded benefits were for 'improved planning skills', though it is interesting that the combined score for 'improved analytic skills' was only 60.6 percent.

\section{Table 8: Personal development outcomes}

\begin{tabular}{|l|l|l|l|l|l|l|}
\hline The items & $\begin{array}{l}\text { Very } \\
\text { Useful }\end{array}$ & Useful & $\begin{array}{l}\text { No } \\
\text { difference }\end{array}$ & $\begin{array}{l}\text { Not } \\
\text { Useful }\end{array}$ & $\begin{array}{l}\text { Not very } \\
\text { useful }\end{array}$ & Total \\
\hline $\begin{array}{l}\text { Has been useful in understanding your } \\
\text { responsibility for your own learning }\end{array}$ & $71(43.0)$ & $35(21.2)$ & $23(13.9)$ & $17(10.3)$ & $19(11.5)$ & $165(100.0)$ \\
\hline $\begin{array}{l}\text { Has improved your comprehension } \\
\text { of the subject }\end{array}$ & $\begin{array}{l}67 \\
(40.6)\end{array}$ & $\begin{array}{l}38 \\
(23.0)\end{array}$ & $\begin{array}{l}33 \\
(20.0)\end{array}$ & $\begin{array}{l}16 \\
(9.7)\end{array}$ & $\begin{array}{l}11 \\
(6.7)\end{array}$ & $\begin{array}{l}165 \\
(100.0)\end{array}$ \\
\hline Improved your planning skills & 68 & 43 & 21 & 26 & 7 & 165 \\
$(1.2)$ & $(26.1)$ & $(12.7)$ & $(15.8)$ & $(4.2)$ & $(100.0)$ \\
\hline Improved your analytic skills & 60 & 40 & 27 & 29 & 9 & $\begin{array}{l}165 \\
(100.0)\end{array}$ \\
\hline
\end{tabular}


As noted above, analysis is an essential key skill for learning and for problem-solving at tertiary level, so it is a concern that the effects of AL were not higher. Related to this point, almost one-quarter (23.1 percent) provided a combined negative score for the analytic skills, stating that they had not derived any benefit from AL. Similarly, the score for 'responsibility for own learning' was supported by only 64.4 percent, and while this is an endorsement of the personal benefits of AL nevertheless it is surprising that the personal outcomes were not more strongly reported.

\section{The interviews}

Interviews were conducted with four teachers who had conducted classes using AL techniques. Three of the interviewees had been teaching for two years using active learning. One had been using it for a year. Of the four participants, three had used traditional methods in the past. Two said that they preferred to use active learning approaches, whereas the other two said that they used both active and traditional lecturing approaches. Interviewees were asked the following questions:

Question 1. Do you think that the students have benefitted from AL?

All responded that active learning had achieved positive results for students, with students benefiting in several ways. The following comment by interviewee \#1 was typical of the replies:

'The attitude of most of the students has changed drastically from being afraid of the course to being happy with it'. 'I have found that there has been an improvement in students' English language, communication skills, presentations and responsibility for their own learning. Students now work as team members, think things through and have developed their problem-solving techniques, which they will use throughout life'.

Question 2. Is the classroom setting appropriate for AL?

The overall opinion was that not all of the classrooms were suitable for the active learning techniques. Some said that several classes were too large and others commented that the some of the classroom facilities were unsuitable.
Question 3. What resources would you like?

All said that there were sufficient resources at the university, but enlarged space for student activities and projects would be beneficial.

Question 4. What obstacles are encountered by staff using AL methods?

The replies were mixed, though overall the respondents considered that all obstacles could be addressed. In reply, interviewee \#2 commented: 'I would like to say that in the final analysis, the AL system has satisfied most of its objectives, which is important to the accreditation process in many programs, especially engineering'.

Question 5. Have you had any training on AL?

All of the interviewees had received four weeks inhouse training on delivering active learning.

In addition to the four teachers, two students were interviewed. The results of these interviews confirmed what was found in the questionnaire survey. Both were positive in their assessment of active learning, commenting that AL techniques had improved their abilities. For example, student \#1 commented: 'We enjoyed learning by using active methods. We acquired a lot of good skills, which we feel are very important in all aspects of our lives. Our English language has improved and the course has strengthened the social relations between us through teamwork. We have developed to be creative in solving problems.

\section{Focus Group}

The three participants were asked about the effectiveness of AL methods, the skills which the students may have acquired, their experiences (both positive and negative) of AL techniques, the obstacles to the use of $\mathrm{AL}$, and how $\mathrm{AL}$ techniques could be improved?

All participants were strongly of the view that students benefitted, and they observed that students' levels of confidence improved, and that both practical and academic skills were strengthened. Students gained the experience of working in teams and groups, which would benefit them in the workaday world. They also improved their ability to understand the course material, took more responsibility for their own learning, were able to 
analyse problems more effectively and could find solutions to problems more successfully.

Negative experiences focused on the problem of classes being too large and the time required by teachers to prepare AL methods. It was also felt that a student evaluation of the active learning program would be beneficial.

\section{DISCUSSION}

The first research question posed for this investigation was, 'Which AL strategies do students at a university in Saudi Arabia find most useful? In response, the central finding of this enquiry was that the majority of students provided positive and supportive reports about AL methods, most commenting that the methods enhanced their learning to some extent. The AL methods which received strongest endorsement were the use of informal classroom settings, the opportunity to work collaboratively in groups, and the use of group discussions for analysing problems and understanding topics. Several AL methods were accorded response rates of about 70 percent approval: interestingly, even though it required more work by the students the use of reflective journals was considered to be beneficial (72.8 percent approval) because it helped them to focus their thoughts on the current subjects. The use of informal classroom settings (83 percent approval) was strongly favoured, this arrangement reportedly facilitating discussion, and small-group activities (70.9 percent support) were said to be useful aids to learning, as were teacher-issued checklists and worksheets.

The second research question was, 'What are the perceptions of students with regard to how AL strategies affected their learning?' Considered overall, most students stated that AL methods positively affected their learning, the improvements extending widely and included comprehension, planning, skills in analysis and IT, and methods of communication. All of these benefits were said by the students to have aided their own understandings and yielded higher results. It was evident, too,

that $\mathrm{AL}$ produced personal and developmental advantages for the students, most reporting benefits to their confidence, their ability to speak publically, and to their attitudes to personal responsibility for their own education.

An important finding was that the results were not overwhelmingly positive, a proportion of students (sometimes as many as 20 percent) stating that $\mathrm{AL}$ methods were not more useful than traditional teaching methods; a finding that accords with the comments of previous researchers (Eison, 2010). Moreover, despite the personal reports by students that $\mathrm{AL}$ was enhancing their learning, it was not possible from this enquiry to determine definitively or statistically whether AL methods improved their overall grades or their test/examination results, or that AL achieved outcomes which were measurably better than those which might have otherwise been achieved by traditional (or other) means.

It is pertinent to note, too, that $\mathrm{AL}$ methods did not entirely supplant traditional lectures, most of the teachers commenting that they continued to use teacher- centred talks as a way of complementing AL. It was not entirely clear why lectures continued in common use, thought it appeared that they could be used when there had been insufficient time to prepare active techniques or when the teacher wanted to impart a large amount of information quickly. It was also evident that teachers were sometimes impeded by the lack of suitable facilities, such as large rooms that could accommodate group activities.

Another important finding was the importance of appropriate teacher training. While the participating teachers reported having undertaken some training in AL methods, the training period of just a few weeks seems to have been inadequate. It became clear that teachers needed more time to prepare courses and topics using AL methods and that they had to devise new approaches for assessing students who had undertaken group work or some other collaborative activity.

The findings of this study confirm the value of AL as a way of enhancing learning by tertiary students. It shows that there are many ways in which students can be assisted to more effectively learn subjects, develop analytical skills, and solve problems. It confirms, also, that teachers need to be provided with both suitable training and facilities if AL methods are to be applied in useful ways. The value of $\mathrm{AL}$ needs to be disseminated more widely 
amongst universities, and the case in support of AL would be strengthened if quantitative studies could show convincingly that learning outcomes and student grades can be elevated by the use of AL.

\section{REFERENCES}

Ahmed G, (2008) “ The impact of active learning approach on improving the reading skills in native language teaching". Journal of Language and Linguistic Studies, Vol.4, No.2, October 2008

Al Sadawwi,A.S,(2010). Saudi National Assessment of Educational Progress (SNAEP). International Journal of Education Policy and Leadership. Volume 5 Number 11

Allen, M.J., \& Yen, W. M. (2002). Introduction to Measurement Theory. Long Grove, IL: Waveland Press.

Baeten M, Kyndt E, Struyven K \& Dochy F (2010). Using student-centred learning environments to stimulate deep approaches to learning: Factors encouraging or discouraging their effectiveness. Educational Research Review, Vol 5, No 3, pp 243-260.

Baldwin LP (2014). Editorial. Active Learning in Higher Education, 16: 3-10. Bandura, A. (1986). Social foundations of thought and action: A social-cognitive theory. Englewood Cliffs, NJ: Prentice Hall.

Bangert, W .Arthur. (2004). The Seven Principles of Good Practice: A framework for evaluating on-line teaching. Internet and Higher Education 7 (2004) 217-232

Benek-Rivera, J., \& Matthews, V. E. (2004) Active learning with jeopardy: Students ask the questions. Journal of Management Education, 28(1), 104-118.

Bonwell, C.C., and J. A. Eison, (1991). "Active Learning: Creating Excitement in the Classroom," ASHEERIC Higher Education Report No. 1, George Washington University, Washington, DC

Bransford, J., Stevens, R., Schwartz, D., Meltzoff, A., Pea, R., Roschelle, J., et al. (2006). Learning theories and education: Toward a decade of synergy. In P. A. Alexander \& P. H. Winne (Eds.), Handbook of educational psychology (2nd ed., pp. 209-244). Mahwah, NJ: Erlbaum.

Bryman, A. (1994). Integrating quantitative and qualitative research: how is it done?

http://qrj.sagepub.com/content/6/1/97.

Bryman, A. (1988) Quantity and Quality in Social Research. London: Unwin Hyman. Bryman, A. (1989) Research Methods and Organization Studies, Unwin Hyman, London.

Bryman, A. (1992) Quantitative and qualitative research: further reflections on their integration. In Brannen, J. (ed) Mixing Methods: Qualitative and Quantitative Research. Aldershot: Avebury.

Campell, D.T., \& Stanley, J.C. (1963) Experimental and quasi-experimental design for research. Chicago: Rand McNally
Carr, L. T. (1994). The strengths and weaknesses of quantitative and qualitative research: What method for nursing? Journal of Advanced Nursing, 20(4), 716-721

Chance, P. (2005). Learning and Behaviour: Active Learning (5th edition). New York: Wadsworth Publishing

Chickering and Z.F. Gamson, eds, Applying the Seven Principles for Good Practice in Undergraduate Education, New Directions in Teaching and Learning, \#47, San Francisco: Jossey-Bass

Chickering, Arthur W., and Zelda F. Gamson. (1987). "Seven Principles for Good Practice." AAHE Bulletin 39: 3-7. ED 282491.6 pp. MF-01; PC-01

Cohen L, Manion L, \& Morrison K (2007). Research Methods in Education (6th ed). Routledge Publishers, Taylor \& Francis, Oxford, UK.

Collins JW \& O'Brien NP (eds) (2003). The Greenwood Dictionary of Education. Westport. Connecticut, Greenwood Publishing.

Collins, H. (2011). Creative Research: The Theory and Practice of Research for the Creative Industries, AVA Publications.

Cranton, P. (2012). Planning instruction for adult learners (3rd ed.). Toronto: Wall \& Emerson.

Creswell J W (2013). Research Design: Qualitative, Quantitative, and Mixed Methods Approaches. (Fourth Edition). Sage Publishing, New York.

Creswell JW (2012). Qualitative Inquiry and Research Design: Choosing Among Five Approaches. Sage Publishing, NY.

Creswell, J. W., Plano Clark, V. L., Gutmann, M. L., \& Hanson, W. E. (2003). Advanced mixed methods research designs. In A.Tashakkori \& C.Teddlie (Eds.), Handbook of mixed methods in social and behavioral research (pp. 209-240). Thousand Oaks, CA: Sage

Creswell, J.W., and V.L. Plano Clark. (2007) Designing and conducting mixed methods research. Thousand Oaks, CA: Sage Publications.

Das, J. R, Kirby, J. R., \& Jarman, R. F. (1979). Simultaneous and Successive Cognitive Processes. New York: Academic Press.

Das, J.P, Manos, J., \& Kanungo, R.N. (1975) Performance of Canadian native, black and white children on some cognitive and personality tests. Alberta Journal of Educational Research, 2(3), 183-195

Denzin, N. K. (1978). The Research Act: An Introduction to Sociological Methods. (Chap. 10). New York: McGraw-Hill.

Denzin, N., and Y. Lincoln. (2005). The discipline and practice of qualitative research. In The Sage Handbook of Qualitative Research, 3rd edition, eds. N. Denzin and Y. Lincoln, 1-32. Thousand Oaks, CA: Sage Publications

Devellis, R.F. (1991) Scale Development: Theory and Applications, Applied Social Research Methods. Series 26, Sage: Newbury Park

Dewey, J. (1897). My pedagogic creed. The school journal. LIV (3): 77-80. 
Dewey, John. (1916/1944). Democracy and Education: An Introduction to the Philosophy of Education. New York: The Free Press

Dorestani, A. (2005). Is interactive learning superior to traditional lecturing in economics courses? Humanomics, 21(1/2), 1-20

Driver R (2007: 1989). Students' conceptions and the learning of science. International Journal of Science Education, Vol 11, Issue 5, 1989

Duffy, M.E. (1985). Designing research the qualitative quantitative debate. Journal of Advanced Nursing, 11, 3, 225-232.

Duffy TM, Lowyck J \& Jonassen DH (2012). Designing Environments for Constructive Learning, Springer Publishing New York.

Dunn, R. (2007). Learning Styles and their Impact in Training. Available:

http://www.sierra-training.com. Last accessed 2012.

Dunn, R. \& Dunn, K. (1993) Teaching secondary students through their individual learning styles. Practical Approaches for grades $7-12$. Allyn \& Bacon: Needham Heights, Ma.

Dunn, R. \& Dunn, K. (1999). The complete guide to the learning styles in service system. Boston: Allyn and Bacon.

EDUCATIONAL SYSTEM IN SAUDI ARABIA (2006). Available: http://Website: www.sacm.org. Last accessed 2010.

Eison,J. (2010). Using Active Learning Instructional Strategies to Create Excitement and Enhance Learning

Feilzer MY (2010). Doing Mixed Methods Research Pragmatically: Implications for the Rediscovery of Pragmatism as a Research Paradigm. Journal of Mixed Methods Research, vol. 4 no. 1 6-16

Felder, R. M.; Brent, R. (2009). Active Learning: An Introduction. ASQ Higher Education Brief, 2(4). Disponível em:

Fink, L. D. (2003) Creating significant learning experiences: An integrated approach to designing college courses. San Francisco: Jossey-Bass

Galliers, R. J. (1991). Choosing Appropriate Information Systems Research Approaches: A Revised Taxonomy. In Information Systems Research: Contemporary Approaches \& Emergent Traditions. (eds. Nissen, H. E.; Klein, H. K. \& Hirschheim, R.), pp. 327 - 345, Amsterdam: North Holland

Garry, B. (2010). Problem Based Learning, the Socratic Method and Semiotic Mediation - A Case Study. University of Dublin.

Greenbaum, T. L. (1998). The handbook for focus group research (2nd ed.). Thousand Oaks, CA: Sage.

Greeno, J. G. (2006). Learning in activity. In R. K. Sawyer (Ed.), The Cambridge handbook of the learning sciences (pp. 79-96). New York: Cambridge University Press.

Guba, EG and Lincoln, YS. (1994). 'Competing paradigms in qualitative research.'
In Denzin NK \& Lincoln YS (eds.) Handbook of Qualitative Research. pp. 105-117.

Gunnison, J.A., Kaufman, N. \& Kaufman, A. (1982) Reading remediation based on sequential and simultaneous processing: Academic Therapy.

Hackathorn J, Solomon ED, Blankmeyer KL, Tennial RE, \& Garczynski AM (2011). Learning by Doing: An Empirical Study of Active Teaching Techniques. Journal of Effective Teaching, Vol. 11, No. 2, pp 40-54.

Hake, RR (1998). Interactive-engagement versus traditional methods: A six- thousand-student survey of mechanics test data for introductory physics courses. American Journal of Physics, 66, 64.

Healey, Mick and Roberts, Jane (2004) "Engaging Students in Active Learning: Case

Hirschheim, R. (1985), "Information systems epistemology: an historical perspective" in Research Methods in Information Systems, Mumford

Howard, P., Perry, B., \& Wong N. (2006). Comparing primary and secondary mathematics teachers' beliefs about mathematics, mathematics learning and mathematics teaching in Hong Kong and Australia. In Mathematics education in di erent cultural traditions: A comparative study of East Asia and the West eds.

Huang, A.H. and Carroll, R.G. (1997). Incorporating active learning into a traditional curriculum. American Journal of Physiology 273 S14-S23

Hamdan, A. (2014). The Reciprocal and Correlative Relationship Between Learning Culture and Online Education: A Case from Saudi Arabia. Available: http://www.irrodl.org/index.php/irrodl/article/view/1408/27 73. Last accessed 2015.

International Learning Styles Network (2008). About learning styles. Retrieved August 6, 2009, from http://www.learningstyles.net/ index.php?option=com_content\&task=view\&id=20\&Itemi $\mathrm{d}=70$ \&lang=en

Johnson, D. W., Johnson, R. T., \& Smith, K. A. (1991) Active learning: Cooperation in the college classroom. Edina, MN: Interaction Book Company.

Johnson, R. B., \& Onwuegbuzie, A. J. (2004) Mixed methods research: A research paradigm whose time has come. Educational Researcher, 33(7), 14-26

Jones, L. (2007). The student-centered classroom. New York: Cambridge University Press.

Kaplan, B., \& Duchon, D. (1988). Combining qualitative and quantitative methods in information systems research: A case study. MIS Quarterly, 12(4), 571-587. Retrieved from http://www.jstor.org/stable/ 249133.

Kilroy DA (2004). Problem-based learning. Journal of Emergency Medicine, 21:411- 413. doi: 10.1136/emj.2003.012435 (THIS IS CRITICAL OF PBL)

Kolb AY \& Kolb DA (2008). 'Experiential Learning Theory: A Dynamic, Holistic Approach to Management Learning, Education and Development' in Armstrong S J \& Fukami C (Eds.) Handbook of Management Learning, Education and Development. London: Sage Publications. 
Kolb, D. (1984) Experiential learning. Upper Saddle River, NJ: Prentice-Hall. Kolb, D. (1985) Learning style inventory. Boston: McBer.

Krueger, R. A., \& Casey, M. A. (2000) Focus groups: A practical guide for applied researchers (3rd ed.). Thousand Oaks, CA: Sage.

Kuh, G. (2008). "High Impact Educations Practices: A Brief Overview." Excerpted from High Impact Educational Practices: What They Are, Who Has Access to Them, and Why They Matter. AAC\&U. Downloaded from the worldwide web on 3/14/2010: http://www.aacu.org/LEAP/hip.cfm.

Kuhn, T. S. (1970). The Structure of Scientific Revolutions.2nd edition Chicago, University of Chicago Press

Landreneau, K.J. (2005) Sampling Strategies. North American Transplant Coordinators Organization Resource Council online web page publications

Lewis S (2004). Active learning methods; physical, biological, and social sciences. [Monograph] Academy Publishing, Sydney.

Lieberman, D.A. (1999). The researcher's role in the design of children's media and technology: Chapter in A. Druin (Ed.), The design of children's technology. San Francisco: Morgan Kaufmann Publishers.

Lord, Thomas R. (1997). A Comparison Between Traditional and Constructivist Teaching in College Biology. Innovative Higher Education. Vol. 21, No. 3:197216.

Lunsford, B.E., and M.J.R. Herzog. (1997). Active learning in anatomy and physiology: Student reactions and outcomes in a non-traditional $\mathrm{A}$ and $\mathrm{P}$ course. The American Biology Teacher 59 (2): 80-84

Mason, J. (2002) Qualitative researching ( $2^{\text {nd }}$ edition). Thousand Oaks, CA.: Sage Publications.

McCarthy, B. (1980). The 4MAT® System: Teaching to learning styles with right/left mode techniques. Barrington, IL: Excel.

McClintock, et al (1979) "Applying the logic of sample surveys to qualitative case studies". Administrative Science Quarterly, 24 (12) 4

McIntosh N. (1996). Why Do We Lecture? JHPIEGO Strategy Paper \#2. JHPIEGO Corporation: Baltimore, Maryland.

McKeachie, W. (1972). "Research on College Teaching," Educational Perspectives, Vol. 11, No. 2, pp. 3-10.

McKinney, K. (2010). "Active Learning. Illinois State University". Center for Teaching, Learning \& Technology.

Messick, S. (1973). Multivariate models of cognition and personality: The need for both process and structure in psychological theory and measurement. In J.R. Royce (Ed.), Contributions of multivariate analysis of theoretical psychology. N.Y: Academic Press

Michael J (2006). Where is the evidence that active learning works? Advances in Physiology Education. Vol. 30 no. 4, pp 159-167.
Michael, J.A. (2003) Active Learning in Secondary and College Science Classrooms. London Lawrence Erlbaum Associates, Publishers

Michel, Norbert. Cater, John. Varela, Otmar (2009). "Active versus Passive Teaching Styles: An Empirical Study of Student Learning Outcomes". Nicholls State University, Small Business Instutite, National Proceedings Vol. 33, No. 1.

Miles, M. B. \& Huberman, A. M. (1994). Qualitative data analysis (2nd ed.). Thousand Oaks, CA: Sage.

Millis, B., and P. Cottell, Jr. (1998). Cooperative Learning for Higher Education Faculty. American Council on Education, ORYX Press, 1998.

Miner, F. C., Jr., Das, H. \& Gale, J. (1984). An investigation of the relative effectiveness of three diverse teaching methodologies: Organizational Behavior Teaching Review, 9(2), 49-59

Moon JA (2004). A Handbook of Reflective and Experiential Learning: Theory and Practice. Psychology Press, London.

More, A. J. (1984) Okanagan/Nicola Indian quality of education study. Penticton: Okanagan Indian Learning Institute.

More, A.J. (1987) Native Indian learning styles: A review for researchers and teachers. Journal of American Indian Education, 27 (1), 17-29.

Miner, F. C., Jr., Das, H. \& Gale, J. (1984). An investigation of the relative effectiveness of three diverse teaching methodologies. Organizational Behavior Teaching Review, 9(2), 49-59

Morse, J.M. (1991). Approaches to qualitative-quantitative methodological triangulation. Nursing Research 40: 12023.

Moses, JW \& Torbjørn LK (2012). Ways of Knowing: Competing Methodologies in Social and Political Research. ( $2^{\text {nd }}$ ed.) New York: Palgrave.

Moskal, B. M., Leydens, J. A., \& Pavelich, M. J. (2002). Validity, reliability and the assessment of engineering education. Journal of Engineering Education, 91(3), 351

Neff, L.S. (Non). Lev Vygotsky and Social Learning Theories. Available: http://www.learningtheorieswebsite/vygotsky.htm. Last accessed 2012.

Newman, I., \& Benz, C. R. (1998) Qualitative-quantitative research methodology: Exploring the interactive continuum. Carbondale, Illinois: Southern Illinois University Press.

Nunnally, JC. (1978). Psychometric theory. New York: McGraw-Hill.

Onwuegbuzie, A. and Leech,N. 2005. "Taking the "Q" Out of Research: Teaching Research Methodology Courses without the Divide Between Quantitative and Qualitative Paradigms." Quality and Quantity 39:267-296.

Ormrod, J. E. (2008). Human learning (5th ed.). Upper Saddle River, MJ: Pearson Education.

OSET website, (2006). Support for Effective Teaching. The University of New Mexico, Albuquerque, NM 87131, (505) 277-0111 
Pashler, H., McDaniel, M., Rohrer, D., Bjork, R., (2008). Learning styles: Concepts and evidence. Psychological Science in the Public Interest 9 (3), 105-119

Piaget J. (1964). The Construction of Reality in the Child. New York: Base Books.

Plush SE, \& Kehrwald BA (2014). Supporting New Academics' Use of Student

Centred Strategies in Traditional University Teaching, Journal of University Teaching \& Learning Practice, 11(1), 2014.

Prince, (2004). "Does Active Learning Work? A Review of the Research." Journal of Engineering Education, 93, (3), 1-9.

Remenyi, D., \& Williams, B. (1996). The Nature of Research: Qualitative or

Quantitative, Narrative or Paradigmatic? Information Systems Journal, 6, 131- 146.

Remenyi, D., Williams, B., Money, A. \& Swartz, E. (1998) Doing research in business and management: An introduction to process and method. London: Sage.

Robinson, V (2011). Student-centered leadership. JosseyBass, San Francisco, California.

Richardson,J. (2005). Students' Approaches to Learning and Teachers' Approaches to Teaching in Higher Education.

Sandelowski, M. (1986). The problem of rigor in qualitative research. Journal of Science, 8, 3, 27-37.

Sarason, Y., \& Banbury, C. (2004). Active learning facilitated by using a game-show format or who doesn' $t$ want to be a millionaire? Journal of Management Education, 28(4), 509-519

Saunders, M., Lewis, P. and Thornhill, A. (2000) Research methods for business students. 2nd edition. Harlow: Pearson Education.

Sawyer, R. K. (Ed.). (2006). The Cambridge Handbook of the Learning Sciences. New York: Cambridge University Press.

Schostak,J.F.(2008). Key themes in Qualitative Research and Enquiry Based Learning: Education in Dialogue, Open University press

Schunk, D. (2008). Learning theories: An educational perspective (5th ed.). Upper Saddle River, NJ: Prentice Hall.

Senemoglu, N. (2002) Gelisim, Ögrenme ve Ögretim (Development, Learning and Teaching) Ankara: Gazi Kitabevi.

Silberman, M. L. (1996) Active Learning: 101 Strategies to Teach Any Subject. Boston: Allyn \& Bacon

Silverman D [Ed] (2011). Qualitative Research, (3 ${ }^{\text {rd }}$ Edition). Sage Publishing, California.

Smith, K.A. (1996). Cooperative learning: Making "groupwork" work. In C. Bonwell \& T. Sutherlund, (Eds), Active learning: Lessons from practice and emerging issues. New Directions for Teaching and Learning 67, 71-82. San Francisco: Jossey-Bass
Snape, D. \& Spencer, L. (2003). The foundation of qualitative research. Ritchie, J. \& Lewis, J. (eds.) Qualitative Research Practice: A Guide for Social Science Students and Researchers, 1-23. London \& Thousand Oaks: Sage.

Stewart-Wingfield, S., \& Black, G. S. (2005). Active versus passive course designs: The impact on student outcomes. Journal of Education for Business, 81(2), 119-125

Tan, O.S. (2004) Editorial. Special issue: Challenges of problem•based learning. Innovations in Education and Teaching International, 41 (2), 123-•124.

Tan, O.S. (2004) Cognition, Metacognition, and Problem•based Learning. In Tan, O.S. (Ed.). Enhancing thinking through problem • based learning approaches: International perspectives, p.1•16. Singapore: Thomson Learning.

Tan, O.S. (2003). Problem•based learning innovation: Using problems to power learning in the 21 st century. Singapore: Thomson Learning.

Teddlie, C. \& Tashakkori, A., (2003). The past and future of mixed methods research: From data triangulation to mixed model designs. In A. Tashakkori \& C. Teddlie (Eds.), Handbook of mixed methods in social \& behavioral research (pp. 671-702). Thousand Oaks, CA: Sage

Tinajero, C., \& Páramo, M. F. (1998). Field dependence-independence and academic achievement: A re-examination of their relationship. The British Journal of Educational Psychology, 67, 199-212

Van Maanen, J. (1979). 'Reclaiming qualitative methods for organizational research: a preface'. Administrative Science Quarterly, 24, 520-6

Van Maanen, J., 1983, Qualitative Methodology, Sage, London

Vygotsky, L.S. (1962). Thought and Language. Cambridge, MA: MIT Press. (Original work published in 1934)

Vygotsky, L.S. (1978) Mind in Society: The development of higher psychological processes. Cambridge, MA: Harvard University Press

Walker SE (2003). Active Learning Strategies to Promote Critical Thinking. Journal of Athletic Training; 38(3): 263267.

Walliman, N. S. \& Walliman N. (2011). Research methods: the basics. Taylor and Francis, New York.

Walonick, D. (2000) Questionnaires and Survey Design, http://www.philseflsupport.com/questionnaires.html

Weimer, M. (2002) Learner-Centered Teaching: Five Keys Changes to Practice. USA: Jossey-Boss

Whetten, D. A., \& Clark, S. C. (1996). An integrated model for teaching management skills. Journal of Management Education, 20(1), 152- 18

Wilke, R. R. (2003). The effects of active learning on student characteristics in a human physiology course for non-majors. Advan Physiol Educ., 27, 207-223

Wood DF (2003). Problem based learning. British Journal of Medicine, 326(7384): 328-330. 
Yager, RE. (1991). The constructivist learning model: towards real reform in science education. Science Teacher 58: $52-57$

Zoller,K and Harrison,B. (2007). "We can teach the way we were taught, or we can teach the way people learn". Available: http://www.sierra-training.com. Last accessed 2012.
Yew, EHJ \& Schmidt HG (2011). What students learn in problem-based learning: A process analysis. Instructional Science 40 (2): 371-95. 